\title{
PERKEMBANGAN SOSIAL EMOSIONAL DAN KREATIVITAS ANAK USIA DASAR
}

\author{
Firdaus Firmansyah \\ Pascasarjana Program Studi Pendidikan Guru Madrasah Ibtidaiyah, \\ FITK-UIN Sunan Kalijaga, Yogyakarta \\ firdausfirmansyyah@gmail.com
}

\begin{abstract}
Abstrak
Perkembangan sosial-emosional merupakan salah satu aspek perkembangan yang sangat penting bagi setiap anak, karena merupakan salah satu faktor penentu kesuksesannya di masa yang akan datang. Peran dan perhatian dari orang tua dan juga seorang pendidik kepada anaknya sangat berpengaruh kepada proses perkembangan sosial-emosinya, setiap anak mempunyai potensinya masing-masing dan juga karakter yang harus dibentuk sejak usia dasar. Tujuan penulisan ini adalah untuk mengetahui perkembangan sosial-emosional terhadap kreativitas anak usia dasar melalui pemahaman dari seorang guru dan juga peran orang tua tentang sosial-emosi anak dan juga potensi yang dimilikinya, serta untuk mengetahui betapa pentingnya seorang anak yang memiliki kreativitas dalam menuangkan sosial-emosinya baik dalam proses pembelajaran di kelas maupun bakat yang dimilikinya. Penulisan ini menggunakan pendekatan kualitatif dengan teknik pengumpulan data yang dilakukan melalui wawancara dan observasi. Analisa selama pengumpulan data yang dilakukan yakni dengan menggunakan analisa narasi deskriptif dan studi pustaka.

"Peran dari seorang guru atau pendidik sudah baik dalam memahami sosial-emosional anak dengan kreativitas yang dimiliki serta mengetahui mau diarahan kemana si anak didiknya tersebut untuk melangkah lebih jauh lagi, supaya potensi anak bisa maksimal berjalan sesuai dengan kemampuan yang dimilikinya, yaitu dengan cara melibatkan warga madrasah dan tentunya peran orang tua dari setiap anaknya. Pihak atau warga madrasah hendaknya lebih memperhatikan karakter sosial-emosional dari setiap peserta didik untuk bisa memunculkan kreativitas yang dimiliki dari setiap anak. Tentu disini tidak sepenuhnya tanggung jawab dari seorang guru saja, harus melibatkan seluruh warga madrasah dan juga peran orang tua siswa.
\end{abstract}

Kata Kunci: Perkembangan Sosial-Emosional, dan Kreativitas Anak di Usia Dasar 


\begin{abstract}
Social emotional development is one aspect of development that is very important for every child, because it is one of the determining factors for his future success. The role parents and educators towards their children is very influential in their socioemotional development, every child has the potential and also the character that must be formed early on. The purpose of this paper is to determine the social-emotional development of creativity of elementary age children throught the understanding of a teacher, the role of parents about the child's social-emotions and also the potential of the child, and to find out how important a child who has creativity in pouring socialhis emotions both inside and outside the classroom of the talent possessed. This writing is qualitative approach to data collection is done by using descriptive narrative and literature study.

"The role of educators is already good in understanding the social-emotional of children with the creativity they have and knowing that they want to be directed where goes further, so that the child's potential can run optimally in accordance with his abilities, by involving the madrasas and the role of parents, from very child". Madrasas parties or citizens should pay more attention to the social-emotional of each student to be able to bring out the creativity possessed by each child. Of course here is not entirely the responsibility of a teacher, it must involve all madrasa residents and also the role of parents of students.
\end{abstract}

Keywords: Social-Emotional Development, and Children's Creativi 


\section{Pendahuluan}

Mengajar dalam konteks proses pembelajaran tidak hanya sekedar mempunyai materi pembelajaran, akan tetapi juga dimaknai sebagai proses mengatur lingkungan supaya peserta didik mau untuk belajar. Walaupun istilah yang digunakan "pembelajaran”. Tidak berarti guru harus menghilangkan perannya sebagai pengajar. Dalam konteks pembelajaran, sama sekali tidak berarti memperbesar peranan peserta didik disatu pihak dan memperkecil peranan guru dipihak lain. Guru dan peserta didik yang dimaksud di sini adalah berkaitan dengan peran dalam proses pembelajaran. Guru dan peserta didik merupakan faktor penentu yang sangat dominan dalam pendidikan umumnya, karena guru dan peserta didik memegang peranan dalam proses pembelajaran, di mana proses pembelajaran merupakan inti dari proses pendidikan secara keseluruhan yang bertujuan terjadinya perubahan tingkah laku anak (Askhabul Kirom: 2017: 16).

Pembelajaran disini tentunya tidak hanya untuk mengetahui kemampuan intelektualnya saja, namun lebih dari itu bahwa ada perkembangan karakter yang harus dbentuk dari pembiasaan yang baik melalui kreativitas peserta didik yang diarahkan langsung oleh seorang guru. Perkembangan menghasilkan bentuk dan ciriciri kemampuan baru yang berlangsung dari tahap aktivitas yang sederhana ke tahap yang lebih tinggi. Perkembangan itu bergerak secara berangsur-angsur tetapi pasti, melalui suatu bentuk tahap ke bentuk tahap berikutnya, yang semakin hari semakin bertambah maju (Desmita, 2012: 9-10).

Berbicara perkembangan tentunya sangat banyak, salah satunya adalah perkembangan sosial-emosional anak karena perkembangan memang mempunyai peran masing-masing dalam poses pertumbuhan dari setiap anak, baik itu perkembangan kognitif, sifat, ataupun psikomotornya. Meski sosial dan emosional adalah dua kata yang memiliki makna yang berbeda, tetapi sebenarnya aspek sosial emosional ini tidak dapat dipisahkan. Hal ini dikarenakan kedua aspek ini saling bersinggungan satu sama lain (Novi Mulyani, 2014: 133).

Perkembangan sosial emosional ini bertujuan supaya anak memiliki keprcayaan diri, kemampuan bersosialisasi, dan kemampuan mengendalikan emosi. Optimalisasi perkembangan sosial emosional ini ditentukan oleh kualitas kerjasama antara orangtua, guru, dan lingkungan (Miranda, dkk, 2015: 1-15).

Adapun perkembangan yang mempengaruhi disini lebih dominan pada reaksi dan karakter yang dimunculkan ketika anak sudah bisa mengkomunikasikan dengan 
teman sebaya nya dan juga mersakan seperti rasa takut, senang dan sedih ketika di lingkungan sekitar, itu terlihat karena adanya perkembangan emosi yang mendominasi otaknya, yang dimaksud disini yaitu perkembangan sosial-emosional anak pada usia dasar, pada anak usia dasar kebanyakan pasti sudah bisa mengutarakan apa yang ia rasakan dari pada yang dilihatnya. Perkembangan sosial-emosional usia dasar perlu diperhatikan untuk mendapatkan perhatian khusus dari pihak orang tua maupun pihak sekolah karena perkembangan sosial-emosional merupakan pengarah bagi siswa untuk berkomunikasi dan berinteraksi secara baik kepada setiap kelompok sosial dan mampu menyesuaikan diri terhadap emosi yang dimiliki kelak (Suyadi, dkk, 2019: 18).

Untuk optimalisasi perkembangan sosial-emosional ini dapat dilakukan dengan cara memulai dengan pengenalan terhadap dirinya sendiri dan juga lingkungan sekitar. Proses pengenalan ini dapat berupa interaksi anak dengan keluarga yang akan membuat anak belajar membangun konsep diri, dan juga dapat dengan cara bermain bersama teman sebaya yang akan melatih dan meningkatkan kemampuan sosialisasi anak (Musringati, 2017: 1-2).

Kemudian, orangtua maupun guru dapat mengembangkan aspek ini melalui beberapa keteladanan, contohnya seperti beribadah, berinteraksi dengan orang lain, bekerja sama, tata cara berpakaian, cara belajar, tentang gaya hidup, dan lain sebagainya (Nurjanah, 2017: 50-61).

Semakin sering perilaku sosial emosional anak dilatih, maka kemampuan problem solving-nya pun akan semakin baik. Maka dari itu orangtua maupun guru harus sesering mungkin mengajak anak bermain permainan yang dapat melatih kemapuan sosial emosional anak. Orangtua dan guru dapat melakukannya melalui metode bercerita, bermain peran, dan sebagainya. Ketika orangtua maupun guru memberikan stimulasi dan intervensi yang baik serta didukung oleh lingkungan yang baik pula, maka kemampuan sosial emosional anak akan berkembang dengan optimal.

\section{Metode Penelitian}

Penulisan ini menggunakan pendekatan kualitatif dengan teknik pengumpulan data yang dilakukan melalui wawancara dan observasi. Analisa selama pengumpulan data yang dilakukan yakni dengan menggunakan analisa narasi deskriptif dan studi Pustaka. Penelitian kualitatif adalah penelitian yang bermaksud untuk memahami fenomena tentang apa yang dialami oleh subyek penelitian misalnya perilaku, persepsi, motivasi, tindakan, dan sebagainya, dan dengan cara deskripsi dalam bentuk 
kata-kata dan bahasa, pada suatu konteks khusus yang alamiah dan dengan memanfaatkan berbagai metode alamiah (Lexy J. Moleong, 2017: 6). Sedangkan dengan jenis penelitian kepustakaan atau library research adalah penelitian yang dilaksanakan dengan menggunakan literatur (kepustakaan), baik berupa buku, catatan atau laporan-laporan hasil penelitian dari peneliti terdahulu.

Adapun metode yang digunakan dalam penelitian ini ialah metode penelitian dengan menggunakan analisis isi (content analysis). Analisis isi merupakan sebuah alat penelitian yang difokuskan pada konten aktual dan fitur internal media. Hal ini digunakan untuk menentukan keberadaan kata-kata tertentu, konsep, tema, frase, karakter, atau kalimat dalam teks-teks atau serangkaian teks. Teks dapat di definisikan secara luas sebagai buku, bab buku, esai, wawancara, diskusi, tajuk berita dan artikel surat kabar, dokumen sejarah, pidato, percakapan, iklan, atau dalam bentuk dokumen (Burhan Bungin, 2012: 173).

\section{Hasil dan Pembahasan}

\section{a. Pengertian Perkembangan}

Perkembangan merupakan bagian dari perubahan yang dimulai dari masa konsepsi dan berlanjut sepanjang rentang kehidupannya. Bersifat kompleks karena melibatkan banyak proses seperti biologis, kognitif, dan sosio-emosional. F.J Monks, dkk (2001) menambahkan pengertian perkembangan merujuk pada proses menuju kesempurnaan yang tidak dapat diulang kembali berdasarkan pertumbuhan, pematangan, dan belajar. Dalam kacamata psikologi, perkembangan dapat diartikan sebagai proses perubahan kuantitatif dan kualitatif individu dalam rentang kehidupannya, mulai dari masa konsepsi, bayi, kanak-kanak, masa remaja, sampai dengan dewasa (Umi Latifah, 2017: 186-187).

Sedangkan menurut Haditono Perkembangan adalah proses yang kekal dan tetap yang menuju ke arah suatu organisasi pada tingkat intergrasi yang lebih tinggi, berdasarkan pertumbuhan dan pemaksaan dalam belajar dan terjadilah suatu organisasi atau struktur tingkah laku yang lebih tinggi. Dalam proses perkembangan sifat individu dan sifat lingkungan menentukan tingkah laku menjadi aktual dan terwujud (S.R. Haditono, 2006: 187).

Ada beberapa alasan mengapa guru atau mahasiswa sebagai calon guru perlu memahami perkembangan peserta didik. Alasan-alasan itu sebagai berikut, mempelajari dan memahami aspek perkembangan peserta didik adalah salah satu 
kompetensi yang harus dimiliki oleh seorang guru, melalui pemahaman tentang aspek-aspek perkembangan serta faktor-faktor yang mempengaruhi perkembangan peserta didik, dapat diantisipasi tentang berbagai upaya memfasilitasi perkembangan tersebut, baik di lingkungan keluarga, sekolah, maupun masyarakat. Disamping itu. dapat diantisipasi juga tentang upaya untuk mencegah berbagai kendala atau masalah yang mungkin akan menghambat perkembangan anak khususnya anak sekolah dasar.

Semua orang memiliki aspek perkembangan yang jumlahnya sama tetapi memiliki kemampuan pengembangan aspek perkembangan yang berbeda-beda. Setiap manusia memiliki kelebihan dan kekurangan masing-masing begitupun anak sekolah dasar. Ada yang unggul dalam hal akademik tetapi rendah dalam hal nonakademik, ada yg unggul aspek kognitifnya tetapi rendah dalam aspek sosial begitupun sebaliknya. Hal tersebut disebabkan oleh beberapa faktor, yaitu faktor gen dan faktor lingkungan.

Perkembangan menghasilkan bentuk dan ciri-ciri kemampuan baru yang berlangsung dari tahap aktivitas yang sederhana ke tahap yang lebih tinggi. Perkembangan itu bergerak secara berangsur-angsur tetapi pasti, melalui suatu bentuk tahap ke bentuk tahap berikutnya, yang semakin hari semakin bertambah maju. Dalam hal ini pada proses perkembangan seorang anak tidak selamanya memiliki sifat yang sama persis dengan masa sebelumnya, seiring berjalannya waktu seorang anak akan mengalami proses dalam kehidupan disekitarnya dimana yang akan mempengaruhi dan menentukan seorang anak tersebut ke dalam proses perkembangannya. Kembali kepada pengaruh orang tua dan seorang pendidik (guru), selain dari faktor eksternal seorang anak juga perlu adanya pertahanan internal yang kuat, karena tidak bisa dipungkiri bahwa setiap anak memliki sifat dan karakter yang berbeda-beda, oleh karena itu faktor internal dari kedua orang tua, keluarga sekitar dan juga pendidik dituntut untuk bisa mengarahkan ke arah yang baik selama dalam proses perkembangannya (Desmita, 2012: 9-10).

Setiap perkembangan memang mempunyai peran masing-masing dalam poses pertumbuhan dari setiap anak, baik itu perkembangan kognitif, sifat, bahasa, ataupun psikomotornya, dll. Adapun perkembangan yang mempengaruhi disini yang dominan dengan reaksi dan karakter yang dimunculkan ketika anak sudah bisa mengkomunikasikan dengan teman sebaya nya dan juga mersakan seperti rasa takut, senang dan sedih ketika di lingkungan sekitar, itu terlihat karena adanya perkembangan emosi yang mendominasi otaknya, yang dimaksud disini yaitu 
perkembangan sosial-emosional anak pada usia dasar, pada anak usia dasar kebanyakan pasti sudah bisa mengutarakan apa yang ia rasakan dari pada yang dilihatnya (Martani Wisnu, 2012: 112).

\section{b. Perkembangan Sosial-Emosional}

Perkembangan sosial merupakan pencapaian kematangan dalam hubungan sosial, dapat juga diartikan sebagai proses belajar untuk menyesuaikan diri terhadap norma, moral, dan tradisi, serta meleburkan diri menjadi suatu kesatuan yang saling berkomunikasi dan bekerjasama (Mayar Farida, 2013: 460).

Perkembangan sosial pada anak-anak Sekolah Dasar ditandai dengan adanya perluasan hubungan di dalam proses pembelajaran dikelas maupun saat bermain di luar kelas, disamping dengan keluarga juga dia mulai membentuk ikatan baru dengan teman sebaya (peer group) atau teman sekelas, sehingga ruang gerak hubungan sosialnya telah bertambah luas.

Sedangkan menurut E. Mulyasa dalam Ginawati perkembangan emosi adalah suatu keadaan atau perasaan yang bergejolak dalam diri seseorang yang disadari dan diungkapkan melalui wajah atau tindakan, yang berfungsi sebagai inner adjustment (penyesuaian dari dalam) terhadap lingkungan untuk mencapai kesejahteraan dan keselamatan individu. Oleh sebab itu perkembangan sosial-emosional di dalam proses pembelajaran maupun saat bermain siswa harus memiliki kesadaran untuk mengembangkan prilaku sosialemosional dengan menyesuaikan berdasarkan lingkungannya.

Menurut Shapiro dalam Putra dan Dwilestari kecerdasan emosional perlu diajarkan sejak dini agar anak tumbuh menjadi seseorang yang dewasa, bertanggung jawab dan mampu menyelesaikan masalah yang dihadapinya. Selain itu, anak yang mempunyai kecerdasan emosional tinggi akan terlihat lebih bahagia, lebih percaya diri dan lebih berprestasi di sekolah. Kecerdasan emosional memiliki dua peran penting bagi anak-anak. Pertama, peran substansial yang berkaitan dengan bagaimana membuat anak dan kehidupannya menjadi lebih manusiawi. Kedua, peran fungsional yang berkaitan dengan bagaimana menggunakan kecerdasan emosional dalam kehidupan seharihari (Nusa dan Ninin, 2013: 50-52).

Perkembangan sosial emosional menurut American Academy of Pediatrics dalam Nurmalitasari adalah kemampuan anak untuk memiliki pengetahun dalam mengelola dan mengekspresikan emosi secara lengkap baik emosi positif, maupun negatif, mampu berinteraksi dengan anak lainnya atau orang dewasa di sekitarnya, serta aktif dalam belajar dengan mengeksplorasi lingkungan. Perkembangan sosial 
emosional adalah proses belajar menyesuaikan diri untuk memahami keadaan serta perasaan ketika berinteraksi dengan orang-orang di lingkungannya baik orang tua, saudara, teman sebaya dalam kehidupan sehari-hari. Proses pembelajaran sosial emosional dilakukan dengan mendengar, mengamati dan meniru hal-hal yang dilihatnya (Femmi, 2015: 103-111).

Perkembangan sosial-emosional adalah suatu teori yang tidak dapat dipisahkan satu sama lain. Dengan kata lain, membahas perkembangan emosi harus bersinggungan dengan perkembangan sosial anak. Keduanya saling terintegrasi dalam bingkai kejiwaan yang utuh. Perkembangan sosial-emosional dipengaruhi oleh sikap, cara, dan kepribadian orang tua dalam memelihara, mengasuh, dan mendidik anaknya

Menurut Dodge, Colker, dan Heroman dalam Hildayani (2009: 10.3), pada masa kanak-kanak awal perkembangan sosial emosional hanya seputar proses sosialisasi. Dimana anak belajar mengenai nilai-nilai dan perilaku yang diterimanya dari masyarakat. Pada masa ini, terdapat tiga tujuan perkembangan sosial emosional. Pertama, mencapai pemahaman diri (sense of self) dan berhubungan dengan oranglain. Kedua, bertanggung jawab atas diri sendiri yang meliputi kemampuan mengikuti aturan dan rutinitas, menghargai oranglain, dan mengambil inisiatif. Ketiga, menampilkan perilaku sosial seperti empati, berbagi, dan mengantri dengan tertib (Rini Hildayani, dkk, 2013: 103.

Perkembangan sosial emosional erat kaitannya dengan interaksi, baik dengan sesama atau benda-benda lainnya. Jika interaksinya tidak baik, maka pertumbuhan dan perkembangan anak menjadi tidak optimal. Namun kebanyakan orangtua kurang memerhatikan hal tersebut pada anak padahal perkembangan sosial emosional setiap anak berbeda. Dalam hal ini peran pendidik sangat diperlukan untuk memahami perkembangan sosial emosional pada anak agar mereka dapat mengembangkan kemampuannya dengan baik.

Perkembangan sosial-emosional usia dasar perlu diperhatikan untuk mendapatkan perhatian khusus dari pihak orang tua maupun pihak sekolah karena perkembangan sosial-emosional merupakan pengarah bagi siswa untuk berkomunikasi dan berinteraksi secara baik kepada setiap kelompok sosial dan mampu menyesuaikan diri terhadap emosi yang dimiliki (Suyadi, 2019: 18).

Usia anak Sekolah Dasar berada pada masa sekolah awal untuk berkembang, masa sekolah awal yaitu fase pada rentang usia 6 sampai 12 tahun atau masa ini sering disebut juga masa kanak-kanak akhir atau masa bermain. Pada masa kanak- 
kanak akhir, perkembangan yang sangat menonjol adalah perkembangan sikap sosial dan emosinya, ditandai dengan mulai hilangnya sikap egosentris yang kemudian berubah pada orientasi sosial. Selain perkembangan sikap sosial, terdapat kemampuan-kemampuan yang hendaknya dimiliki oleh anak usia sekolah dasar yang disebut dengan tugas perkembangan. Siswa sebagai makhluk individu mempunyai tugas perkembangan yang berkaitan dengan kemampuannya menjadi pribadi yang lebih matang sesuai dengan tahap perkembangannya (Hesti Tri Rahayu, 2016: 3-4).

Peran emosi dalam kehidupan anak menjadi penting karena akan mempengaruhi penyesuaian sosial anak, yang mana perkembangan anak usia sekolah dasar yang paling menonjol adalah perkembangan sikap sosial. Selain itu emosiemosi positif yang ada dalam diri seseorang dapat mendorongnya untuk berprestasi atau meraih keberhasilan sesuai tujuan yang ditetapkan begitu juga sebaliknya.

Istilah perkembangan sosio-emosional berarti keterampilan yang mendukung dan mengembangkan proses komunikasi yang baik, melalui anak-anak dan diperkenalkan kepada orang tua dan kemudian ke masyarakat yang lebih luas, sementara pada saat yang sama si anak juga kadang memiliki pendapatnya sendiri, dengan koeksistensi kepribadian, perasaan dan organisasi yang semuanya dikontrol oleh karakteristik (Cole \& Cole, 2001).

Ada alasan kuat untuk menjadikan keterampilan dan kompetensi pembelajaran sosial dan emosional sebagai fitur utama di sekolah dasar, bahwa peserta didik yang menguasai keterampilan SEL (Social-Emosional Learning) akan menghasilkan sifat seperti, Anak akan mudah bergaul dengan orang lain baik di sekolah ataupun di lingkungan masyarakat sekitar, dan di sekolah akan baik dengan guru ataupun teman sebaya nya, serta akan memiliki pengetahuan yang lebih luas sedangkan dari segi kesehatan mental dan fisik akan terlihat lebih prima (SM Jones, dkk, 2017).

\section{c. Pengertian Kreativitas}

Menurut Conny dalam Sumantri menerangkan bahwa kreativitas merupakan kemampuan atau kecakapan yang ada dalam diri seseorang, hal ini erat kaitannya dengan bakat. Sedangkan Hulbeck menerangkan bahwa tindakan kreatif muncul dari keunikan keseluruhan kepribadian dalam interaksi dengan lingkungannya (Sumantri, 2016: 85).

Sudut pandang para ahli terhadap kreativitas menjadi dasar perbedaan dari definisi kreativitas. Definisi kreativitas tergantung pada segi penekanannya, kreativitas dapat didefinisikan kedalam empat jenis dimensi sebagai 4 P's Creativity, 
yaitu dimensi Person, Proses, Press dan Product. Dimensi person adalah upaya mendefinisikan kreativitas yang berfokus pada individu atau person dari individu yang dapat disebut kreatif.

Dimensi proses upaya mendefinisikan kreativitas yang berfokus pada proses berpikir sehingga memunculkan ide-ide unik atau kreatif. Sedangkan menurut Munandar menerangkan bahwa kreativitas adalah sebuah proses atau kemampuan yang mencerminkan kelancaran, keluwesan (fleksibititas), dan orisinalitas dalam berpikir, serta kemampuan untuk mengelaborasi (mengembangkan, memperkaya, memperinci), suatu gagasan. Pada definisi ini lebih menekankan pada aspek proses perubahan (inovasi dan variasi).

Dimensi Press, pendekatan kreativitas yang menekankan faktor press atau dorongan, baik dorongan internal diri sendiri berupa keinginan dan hasrat untuk mencipta atau bersibuk diri secara kreatif, maupun dorongan eksternal dari lingkungan sosial dan psikologis. Mengenai "press" dari lingkungan, ada lingkungan yang menghargai imajinasi dan fantasi, dan menekankan kreativitas serta inovasi. Kreativitas juga kurang berkembang dalam kebudayaan yang terlalu menekankan tradisi, dan kurang terbukanya terhadap perubahan atau perkembangan baru.

Dimensi Product merupakan upaya mendefinisikan kreativitas yang berfokus pada produk atau apa yang dihasilkan oleh individu baik sesuatu yang baru/original atau sebuah elaborasi/penggabungan yang inovatif. Dari beberapa uraian mengenai kreativitas yang dikemukakan diatas dapat disimpulkan bahwa : "Kreativitas adalah proses konstruksi ide yang orisinil (asli), bermanfaat, variatif (bernilai seni) dan inovatif (berbeda/lebih baik)".

\section{d. Pentingnya Perkembangan Sosial-Emosional dan Kreativitas Terhadap Anak Usia Dasar}

Pada zaman atau di era 4.0 sekarang ini kebutuhan dari setiap anak berbedabeda dan tentunya menyesuaikan dengan keadaan sekitarnya, dengan zaman yang semuanya hampir serba teknologi ini banyak anak di masa sekarang yang memang baik atau menonjol dalam aspek kognitifnya, namun pada aspek sifatnya menurun seperti kurangnya sifat saling menghargai, yang justru berdampak pada sifat dan kepribadian lainnya.

Perkembangan atau aspek kognitif saat ini berada ditingkatan kedua setelah aspek sikap, itu karena dirasa aspek sikap pada saat ini memang harus dibenahi sesuai 
kurikulum yang berlaku yang berfokus pada perkembangan karakter peserta didik, selain harus dibenahi ada juga peran dan juga perhatian dari orang tua, pendidik, lingkungan sekitar dan kesadaran dari individu itu sendiri. Tidak hanya mengarahkan dalam hal sifatnya saja, akan tetapi peran dari orang tua maupun pendidik juga harus mengetahui kekurangan dan kelebihan yang dimiliki dari setiap anak tersebut.

Perkembangan anak di usia dasar sangatlah rentan, labil dan cenderung memiliki sifat yang mengikuti, oleh karena itu jangan sampai sebagai orang tua dan juga pendidik melakukan kesalahan dalam mengarahkan atau mencetak anak tersebut. Berbicara perkembangan tentunya sangat banyak, ada perkembangan tentang kemampuan intelektual (kognitif), afektif (sikap), keterampilan (psikomotor), perkembangan sosial, perkembangan emosi, perkembangan bahasa, perkembangan moral dan lain-lain. Dalam pembahasan kali ini penulis lebih menekankan kepada perkembangan sosial-emosional anak usia dasar dan karena perkembangan memang mempunyai peran masing-masing dalam poses pertumbuhan dari setiap anak, baik itu perkembangan kognitif, sifat, ataupun psikomotornya.

Oleh karena itu perkembangan sosial-emosional dan kreativitas pada anak usia dasar ini sangat penting untuk dibahas, supaya si anak atau siswa ini minimal bisa mengontrol sikap atau emosinya ketika ia benar-benar mempunyai kebisaan dalam suatu hal, baik itu kemampuan berfikir kritis yang dalam hal ini kemampuan akademiknya atau bakat lainnya yang non akademik seperti bermain futsal, bulutangkis, catur dll. Disini sebenarnnya siswa tidak hanya bisa untuk dapat mengontrol sosial-emosionalnya saja, akan tetapi yang sangat diharapkan supaya siswa juga bisa menemukan kelebihan dan potensi yang dimilikinya, baik dalam ruang lingkup pembelajaran formal maupun non formal.

Seperti yang sudah dijelaskan di atas bahwa perkembangan sosial-emosional ini merupakan suatu perkembangan yang tidak bisa dipisahkan satu sama lain, membahas tentang perkembangan sosial, tentunya harus bersinggungan dengan perkembangan emosi, dan begitupun sebaliknya. Kedua perkembangan ini saling terintegrasi dalam suatu bingkai kejiwaan yang utuh, perkembangan sosial-emosional dipengaruhi oleh sikap, cara, dan kepribadian dari orang tua dalam memelihara, mengasuh, dan mendidik anaknya.

Setelah perkembangan sosial-emosional disini dirasa sudah cukup diarahkan, lalu peran dari orang tua maupun seorang pendidik tidak berhenti sampai disini, bawah perlu adanya kreativitas dari kelebihan yang dimiliki anak tersebut, tentunya 
yang menentukan disini tidak hanya orang tua dan pendidik itu sendiri, perlu adanya obrolan kecil antara orang tua dengan anak, anak dengan pendidik dan pendidik dengan orang tua, hendaknya mau dibawa kemana kreativitas yang dimiliki si anak tersebut. Supaya tidak adanya unsur keterpaksaan yang justru akan membuat si anak itu kebingungan, keseriusan seperti ini yang justru masih dianggap sepele oleh masyarakat banyak tentang perkembangan sosial-emosional yang diarahkan kedalam kreativitas yang dimiliki dari si anak untuk menentukan jalan atau nasib kedepannya kelak.

Contoh dari di atas ada dua, ada contoh yang kurang baik ada juga yang baik, sebagai berikut: contoh kurang baiknya sudah cukup banyak, seperti kurangnya semangat si anak ketika ada keterpaksaan dari orang tua dalam menentukan nasibnya kedepan, belum tentu yang diharapkan orang tua itu baik ketika si anak kurang mampu dalam mengerjakannya, yang justru akan menimbulkan masalah baru. Adapun contoh baiknya ketika ada obrolan antara orang tua dengan anak, anak dengan pendidik, dan pendidik dengan orang tua mengenai nasib si anak tersebut kedepannya, dalam tanda kutip dimusyawarahkan secara baik, baik antara orang tua dengan anak dan orang tua dengan pendidik. Disini akan menemukan titik terang kemana si anak tersebut akan melangkah ketika sudah menemukan kebisaan dan mau diarahkan kemana yang tentunya dengan baik secara maksimal.

\section{Penutup}

Perkembangan sosial emosional merupakan proses dimana anak belajar menyesuaikan diri untuk memahami keadaan serta perasaan ketika berinteraksi dengan orang-orang di sekitar lingkungannya baik dengan orang tua, guru, saudara, dan teman sebaya dalam kehidupan sehari-hari. Perkembangan sosial-emosional erat kaitannya dengan interaksi, baik dengan sesama manusia atau benda-benda lainnya. Jika interaksinya tidak baik, maka pertumbuhan dan perkembangan anak juga menjadi tidak optimal.

Pada zaman atau di era 4.0 sekarang ini kebutuhan dari setiap anak berbedabeda dan tentunya menyesuaikan dengan keadaan sekitarnya, dengan zaman yang semuanya hampir serba teknologi ini banyak anak di masa sekarang yang memang baik atau menonjol dalam aspek kognitifnya, namun pada aspek sifatnya menurun seperti kurangnya sifat saling menghargai, yang justru berdampak pada sifat dan kepribadian lainnya. 
Dengan kita mengetahui perkembangan sosial-emosional peserta didik juga itu akan mampu membuat siswa tersebut bisa lebih kreativitas dalam mengekplorasi sosial-emosinya, dan akan terlihat outputnya ketika peserta didik bisa menyelesaikan masalah yang dihadapinya dalam kehidupan yang sebenarnya baik di lingkungan kelas, sekolah dan masyarakatnya kelak. Minimal dengan peserta didik bisa mampu menganalisis keadaan sekitar dengan apa yang dialami serta bagaimana cara menyelesaikan masalah tersebut. 
Al-Ihtirafiah: Jurnal Ilmiah Pendidikan Guru Madrasah Ibtidaiyah

Vol. 1 No. 2 Desember 2021

\section{DAFTAR PUSTAKA}

Bungin, B. (2012). Metode Penelitian Kualitatif, Aktualisasi Metodologis Ke Arah Ragam Varian Kontemporer. Jakarta: PT Raja Grafindo Persada.

Desmita. (2012). Psikologi Perkembangan. Bandung: Remaja Rosdakarya.

Femmi, N. (2015). Perkembangan Sosial Emosi pada Anak Usia Prasekolah. Buletin Psikologi .Vol.23 (2), 103-111.

Kirom, A. (2017). Peran Guru Dan Peserta Didik Dalam Proses Pembelajaran Berbasis Multikultural. Jurnal Pendidikan Agama Islam Pasuruan, 69.

Latifah, U. (2017). Aspek Perkembangan pada Anak Sekolah Dasar: Masalah dan Perkembangannya. Academica : Jurnal Pembelajaran Multidisipliner IAIN SURAKARTA, Vol. 1 No. 2, 186-187.

Martani, W. (2012). Metode Stimulasi dan Perkembangan Emosi Anak Usia Dini. Jurnal Psikologi Volume 39, No.1, 112.

Mayar, F. (2013). Perkembangan Sosial Anak Usia Dini Sebagai Bibit Untuk Masa Depan Bangsa. Jurnal Al-Ta'lim, Jilid 1 Nomor 6, 460.

Miranda, D. W. (2015). Peningkatan Perkembangan Sosial Emosional melalui Pemberian Tugas Kelompok pada Anak Usia 5-6 Tahun. Universitas Tanjungpura, Pontianak, 1-15.

Moleong, L. J. (2017). Metodologi Penelitian Kualitatif (Edisi Revisi). Bandung: PT Remaja Rosda Karya.

Mulyani, N. (2016). Upaya Meningkatkan Perkembangan Sosial Emosional Anak Usia Dini. Raushan Fikr. Vol. 3 (2), 133-147.

Musringati. ( 2017). Mengembangkan Kemampuan Sosial Emosional Anak Usia Dini pada Kelompok B melalui Metode Bercerita di TK Al Ikhlas. STKIP Siliwangi Bandung, 1-2.

Ninin Dwilestari, N. (2013). Penelitian Kualitatif Pendidikan Anak Usia Dini. Jakarta: PT Raja Grafindo Persada.

Nurjannah. (2017). Mengembangkan Kecerdasan Sosial Emosional Anak Usia Dini melalui Keteladanan. Jurnal Bimbingan Konseling dan Dakwah Islam. Vol.14 (1), $50-61$.

Rahayu, H. (2016). Kematangan Emosi Pada “Asd” Siswa Berprestasi Kelas V-A SD Negeri 4 Wates. Jurnal Pendidikan Guru Sekolah Dasar Edisi 19 Tahun Ke-5 2016 PGSD/PSD, UNY, 3-4.

Stephanie M. Jones, S. P. (2017). Promoting Social and Emotional Competencies in Elementary School. Journal Article, Princeton University: Social and Emotional Learning Vol. 27, No. 1, SPRING.

Sumantri, M. S. (2016). Asesmen Dan Intervensi Pedagogik Dalam Membangun Generasi Emas Ditinjau Dari Perspektif Pengembangan Kreativitas Siswa Kelas Awal Sekolah Dasar. JURNAL PENDIDIKAN DASAR Volume 7 Edisi 1, 85.

Tusyana Trengganis, S. (2019). Analisis Perkembangan Sosial-Emosional Tercapai Siswa Usia Dasar. Jurnal Inventa Vol III. No 1, 18. 